\title{
Is transformational leadership always good for employee task performance? Examining curvilinear and moderated relationships
}

\author{
Yashuo Chen, Ranran Ning, Tong Yang, Shangjun Feng and Chunjiang Yang*
}

\footnotetext{
* Correspondence: ycj@ysu.edu.cn School of Economics and

Management, Yanshan University, Qinhuangdao, Hebei Province 066004, People's Republic of China
}

\begin{abstract}
Transformational leadership, generally considered as a desirable leadership style, has positive effects on various performance outcomes of employees; however, its productivity has been called into question because of a relative neglect of its negative aspects. Addressing this gap, an attempt at rethinking the relationship between transformational leadership and employee performance is important. The paradoxical perspective indicates that conflicting positive and negative effects of transformational leadership can coexist, which provides possibility and rationality for thorough consideration of employees' task performance influenced by transformational leaders. Integrating the principle of diminishing marginal utility and the "Too-Much-ofa-Good-Thing (TMGT)" effect, this research explores an inverted U-shaped relationship between transformational leadership and employee task performance. Furthermore, applying social cognitive theory, we assume an employee's proactive personality moderates the curvilinear influence of transformational leadership on employees' task performance. As expected, results from a study of data from 209 supervisorsubordinate relationships from China showed that the inverted U-shaped relationship between transformational leadership and employees' task performance was moderated by employees' proactive personality. Theoretical and practical implications are discussed.

Keywords: Transformational leadership, Task performance, Proactive personality, Curvilinear relationship, Social cognitive theory
\end{abstract}

Enron, the seventh largest company in the US at its peak, suffered the fate of its final demise the subsequent year. Although "Enron is too complex a story to avail of one single explanation (e.g., an extremely prevalent excessive transformational leadership within the organizational life) for its rise and fall," the undeniable fact is that there were "compelling vision and totalistic vision(s)," "charismatic and extremely powerful" leaders and "higher levels of compliance from followers" on the eve of bankruptcy, which provides some beneficial inspiration to consider the dark side of transformational leadership.

-Tourish 2013, pp.117-133 


\section{Introduction}

Transformational leadership has been one of the most important researched topics of the past few decades since Burns (1978) introduced its concept (Ng 2017). Transformational leadership draws the attention of scholars because of its difference with traditional leadership styles such as directive or transactional leadership (Judge and Piccolo 2004; Kark et al. 2018). Transformational leaders can become role models who are admired, respected and trusted, disburse attention to followers' self-development process, encourage innovation by questioning, refraining, and solving old problems through new methods, and inspire to transcend their personal interests for organizational interests (Avolio and Bass 2002; Bass 1990). Substantial evidence has shown that transformational leaders influence the expression of subordinates' emotions, attitudes and behaviors (Bass 1997; Judge and Piccolo 2004; Liao and Chuang 2007; Bednall et al. 2018). Specifically, the overwhelming majority of studies hold that transformational leadership and desirable individual and organizational outcomes produce a positive linear relationship. For instance, transformational leadership is positively related to emotional intelligence (Brown and Reilly 2008), task performance (Walumbwa et al. 2008; Wang et al. 2005), organizational citizenship behaviors (Podsakoff et al. 1990), organizational commitment (Avolio et al. 2004), occupational safety (Barling et al. 2002), team performance (Dionne et al. 2004; Zhang et al. 2011) and team innovation (Eisenbeiss et al. 2008). According to the notion of "the more, the better," transformational leadership, as a widely accepted beneficial antecedent variable, leads to beneficial consequences.

However, some scholars have indicated that in all seemingly monotonic positive relations there may exist context-specific inflection points which provide clues that previous research has failed to investigate the nature of transformational leadership comprehensively (Grant and Schwartz 2011; Pierce and Aguinis 2011; Bednall et al. 2018). Indeed, emerging empirical literature has revealed mixed and diverse relationships between transformational leadership and favorable behavior outcomes, including positive (Gong et al. 2009; Shin and Zhou 2003), negative (Basu and Green 1997; Osborn and Marion 2009) and non-significant direct relationships (Jaussi and Dionne 2003). These findings suggest that the accepted consensus with respect to the beneficial effects of transformational leadership on outcomes in the workplace are likely to be challenged. Some undesirable consequences of transformational leadership may exist under certain conditions, which have been overlooked in previous research. The inspired leadership may be a double-edged sword (Keeley 1995). In particular, Porter and Bigley (2003) pointed out that transformational leadership could bring about some harmful consequences for organizations. If organizational members are influenced by the competing visions of different transformational leaders, role conflict and role ambiguity of employees could be an obstacle to improving performance and efficiency. Osborn and Marion (2009) demonstrated that transformational leadership is associated with negative performance based on the analysis of 473 individual surveys. In addition, Tourish (2013) argued that transformational leadership had two sides, "the bright side and the dark side." Lee et al. (2016) indicated that there was a curvilinear relationship between empowering leadership and employee task performance. Therefore, based on the consideration of both advantages and disadvantages coexisting in inspired leadership (Keeley 
1995), we posit that there may be a potential curvilinear pattern in the relationship between transformational leadership and desirable outcomes in the workplace, including the nature of employee task performance. Nevertheless, empirical evidence for thoroughly exploring both the advantageous and disadvantageous roles of transformational leadership in engendering followers' organizational behaviors is scarce (Pieterse et al. 2010). Furthermore, less clear is whether an optimal degree of transformational leadership practice exists in the organization of science.

Predicting and explaining employee performance has historically been a considerable and complicated question in the field of organizational research (Barrick et al. 2013). Numerous researchers suggest that performance is the ultimate dependent variable, if not its raison deter (Organ and Paine 1999). To this end, the construct of employees' task performance is adopted as the model's outcome in any study which is influenced by transformational leadership. Specifically, considering this important yet unaddressed issue of the effects of transformational leadership on employee task performance, in this research we empirically examine the potential nonlinear relation (inverted U-shape) in the aforementioned relationship. We address the possibility of existence by adopting a paradoxical perspective confirming that conflicting positive and negative effects of transformational leadership can coexist (Smith and Lewis 2011). Integrating the principle of diminishing marginal utility (referring to the more a benefit is enjoyed, the lower the marginal benefit of the next unit) and TMGT effect (e.g., "Too much of any good thing can lead to unexpected negative outcomes"), transformational leadership, as a typically beneficial antecedent, reaches an inflection point where the relationship with the favorable outcomes ceases to be linear and positive. Concretely, we consider when a leader engages in too many transformational behaviors, a downturn in expected outcome-task performance could occur.

Additionally, with respect to predicting and improving employee performance research, leadership studies rarely focus on the role of employees' meaningful individual differences in the process of leadership influence on their performance outcomes, while the personality literature neglects the significant influence of leadership (Frieder et al. 2018; Ostroff and Bowen 2016; Uhl-bien et al. 2004). Perhaps by taking into account leaders' styles and followers' characteristics, we can better understand performance and suggest important implications for organizational management research and practice. In summary, for enriching employee performance research streams and overcoming a major weakness in each research stream, it is important to recognize two aspectsleaders and followers as causal agents who influence employees' own performance. Felfe and Schyns (2006) has already demonstrated that the perception of leadership is shaped by characteristics of the followers and follower personality characteristics may act as moderators of the relationships between transformational leadership and performance outcomes. A proactive personality is defined as "a dispositional construct that identifies differences among people in the extent to which they take action to influence their environments" (Bateman and Crant 1993, p.103). Because proactive personality inspires individuals to master their own situations or context, the extent of proactive personality may be an important factor in the relationship between transformational leadership and performance. In particular, in the present study, we assume that in the process where transformational leadership influences employee performance, this is thought to be contingent upon the employees' proactive personality. 
This research provides three key contributions to extant transformational leadership and proactive personality literature. First, we answer the fundamental question of "what is the relationship between transformational leadership and employee task performance?" We subscribe to the paradoxical perspective, the principle of diminishing marginal utility and the TMGT effect to demonstrate the inverted U-shaped relationship between transformational leadership and employee task performance. Furthermore, we find that the intermediate levels of transformational leadership may produce optimal task performance of employees which deepens our understanding of transformational leadership. Second, we explicitly investigate how subordinates' proactive personality moderates the curvilinear influence of transformational leadership on employee task performance. It is a response to calls for the examination of boundary conditions of curvilinear relationships more generally (Baer and Oldham 2006; Ren and Chadee 2017). Third, in our model we simultaneously include transformational leadership as the antecedent of task performance and employees' proactive personality as moderator in the influence of transformational leadership on task performance which fills the research gap on leadership that has been heavily leader-focused but with little attention paid to followers as a differentiated group. Overall, this research not only enriches the theoretical knowledge, but also has practical value to management in going beyond the conventional linear relationship.

\section{Literature review and hypotheses development}

\section{Transformational leadership}

Transformational leaders transform their employees' personal values and self-concept into a higher level of organizational needs and aspirations (Avolio et al. 1999). According to Avolio and Bass (1995), transformational leadership has four dimensions. The first is individualized consideration, which is the degree to which a leader builds close relationships with employees and attends to followers' needs and differences, acts as a mentor or a coach to the followers, and listens to the followers' concerns. Intellectual stimulation is the degree to which the leader challenges assumptions, takes risks and stimulates followers to think about old problems in new ways. Inspirational motivation is the degree to which the leader articulates a vision that is appealing and inspiring to followers with high standards, communicates optimism about future goals and provides meaning for the task at hand. Idealized influence means that leaders are admired, respected and trusted, and emphasizes the importance of having a collective sense of mission. These behaviors are deemed more efficient in the "change and transformation" context.

Since the publication of Bass (1985) seminal work, a multitude of studies have documented pervasive and beneficial effects of transformational leadership on followers' attitudinal and motivational outcomes [e.g., job satisfaction (Braun et al. 2013), satisfaction with leader (Bono and Judge 2003), motivation (Charbonneau et al. 2001), organizational commitment (Avolio et al. 2004), effort (Weiß and Süß 2016)], followers' behavioral outcome [e.g., performance (Wang et al. 2005), creativity (Gong et al. 2009; Bednall et al. 2018)] and leaders' outcomes [e.g., leader effectiveness (Erkutlu 2013), leader job performance (Deinert et al. 2015)]. For instance, transformational leadership is positively related to follower perceptions of organizational support, leader-member 
exchange, organizational justice, trust in a supervisor (Ahmad et al. 2008), and psychological empowerment (Castro et al. 2008), while transformational leadership is negatively associated with employee perceived job stress, burnout (Flaschner et al. 2006), work-family conflict (Munir et al. 2012) and turnover (Tse et al. 2013).

Importantly, Seibert et al. (2011) argued that scholars have paid much attention to investigating transformational leadership because of its role in performance beyond expectations over the past quarter century. Therefore, the main content of transformational leadership literature is the potential performance implications of transformational leadership. Meanwhile, primary studies on transformational leadership have involved exploring the "beyond expectation" role of transformational leadership in performance across criterion types, levels of analysis, different study methods and in different settings. In terms of performance, many studies revealed the effects of transformational leadership on follower task performance, contextual performance, and creative performance. In terms of analysis unit, transformational leadership theory suggested that transformational leadership was associated not only with individual performance but also with group and organizational performance (Bass 1985; Conger et al. 2000; Shamir et al. 1993). In additional, Dvir et al. (2002) found that transformational leadership could enhance follower development and performance by a longitudinal, randomized field experiment. Tse and Chiu (2014) indicated that transformational leadership influenced employees' organizational citizenship behaviors according to hierarchical linear modeling which used data from a sample of 250 Chinese front-line employees and their immediate managers working in banks.

\section{Transformational leadership and task performance}

A great deal of evidence has confirmed that transformational leadership is positively associated with a range of outcomes in performance (Bass and Avolio 1990; Kirkpatrick and Locke 1996; Spreitzer et al. 2005). Nevertheless, not every study came to positive conclusions about the influence of transformational leadership on performance outcomes. For instance, according to a study by Voigtländer (2016), transformational leadership is negatively correlated with organizational growth performance when studying the leadership of the CEO of small businesses in the US. In addition, some empirical research showed that there is no statistically significant link between transformational leadership (Kissi et al. 2013; Tosi et al. 2004) and performance of employees (Judge and Piccolo 2004). Furthermore, boundary conditions and a mediating mechanism in the relationship between transformational leadership and employee performance are sufficiently recognized or appreciated by researchers (Menges et al. 2008; Menges et al. 2011; Pan and Lin 2015). Prior research proposed that group-focused transformational leadership is positively associated with team innovation (Jiang et al. 2015), whereas differentiated individual-focused transformational leadership is negatively related to team innovation. Li and Yuan (2017) found that the "bright side" of transformational leadership has a direct positive moderation effect, while the "dark side" has an indirect negative moderation effect via leader-leader exchange when the relationship between proactive personality and career satisfaction is empirically examined. Bednall et al. (2018) argued that the relationship between transformational leadership and follower innovative behavior is non-linear rather than having a positive linear relationship. In 
sum, these dual-side effects may provide clues implying the possibility of a nonlinear relationship between transformational leadership and employee task performance. However, there are few studies to demonstrate empirically the curvilinear effect of transformational leadership on employee task performance. Broadly speaking, task performance refers to the evaluation of the particular tasks and behaviors in traditional job descriptions (Williams and Anderson 1991). Meanwhile, task performance, as an important element, is considered part of employee performance appraisal indicators of almost all organizations (Manesh and Zanjirchi 2013).

A paradox represents contradictory yet coexisting opposing elements (Smith and Lewis 2011). Paradoxical thinking is prevalent in Chinese management practice. The Daoist yin-and-yang symbol posits that everything is paradoxical (Ma and Tsui 2015). Similarly, the Confucian "middle way" denotes the avoidance of polarization (Chen 2003). In addition, dialectic worldviews accept the notion that the world is contradictory, interconnected, and constantly changing (Peng and Nisbett 1999). Everything which exists can theoretically be both good and bad (Spencer-Rodgers et al. 2004). Likewise, Western literature has previously suggested paradoxes in organizations (Lewis 2000; Smith and Lewis 2011; Smith and Tushman 2005). Indeed, scholars have effectively explained organizational phenomena in practice through the paradox perspective (Schad et al. 2016). For example, competition and cooperation (Chen 2008), differentiation and integration (Lawrence and Lorsch 1968), and flexibility and control (Eisenhardt et al. 2010) are important elements for the most effective organizations. In addition, earlier studies indicated that paradoxical leader behaviors in people management are most effective, including maintaining both distance and closeness, treating subordinates uniformly and distinctively and enforcing control while allowing flexibility, all of which apply a paradoxical lens to examine the behaviors of leaders (Zhang et al. 2015). Integrating Eastern management philosophy and Western-based literature, our study explores the nature of transformational leadership by adopting the paradox perspective, which may generate new inspirations in transformational leadership research. Next, we focus on why and what of the two paradox-good and bad effects of transformational leadership on employee performance.

The law of diminishing marginal utility is pervasive in our daily life and workplace; for example, the more you travel to a place, the less novel it is. Diminishing marginal utility is initially a basic economic principle which states that as more of a product or service is consumed, the marginal benefit of the next unit decreases. If you consume too much, the marginal utility of a product or service can become negative (Easterlin 2005; Rabin et al. 2001). Diminishing marginal utility has been further extended to the organizational management field (Dhanaraj and Beamish 2004). In social management, once a favorable policy is issued, the management effect is often obvious in the beginning; however, as time goes by, the policy's function becomes weaker and less suitable for the need of the social management. This is why the legal and policy departments adjust and update policies at times (Robalino et al. 2009). It is the same within organizational management. This principle may suggest that transformational leadership and its "marginal utility" do not have a linear relationship, which means any specific change in transformational leadership will always produce a corresponding fixed value change in the "marginal utility" in the area of management. 
In addition, the TMGT effect was presented by Pierce and Aguinis (2011) to account for many paradoxical and anomalous empirical results in modern organizations and management which provides additional and persuasive support for explanation of the transformational leadership influence on employees' performance. "The TMGT effect occurs when ordinarily beneficial antecedents (i.e., predictor variables) reach inflection points after which their relations with desired outcomes (i.e., criterion variables) cease to be linear and positive. Exceeding these inflection points is always undesirable because it leads either to waste (no additional benefit) or, worse, to undesirable outcomes (e.g., decreased individual or organizational performance)" (Pierce and Aguinis 2011, p. 315). Ames and Flynn (2007) demonstrated that the assertiveness of a leader has an inverted U-shaped relationship with leadership effectiveness of employees. Similarly, Lee et al. (2016) also indicated the same relationship existing between empowering leadership and employee performance. The accumulation of quantitative changes results in qualitative changes (Olsen 2004). Namely, the positive relationship between transformational leadership and employee task performance evolves into a negative effect of transformational leadership on employee performance. The bright and dark sides of transformational leadership would both play important roles in any situation. Shedding light on the negative side effects of transformational leadership may help explain the mixed picture of empirical findings. Beyer (1999) and Yukl (2009) stressed that negative effects of transformational and charismatic leadership have been neglected and deserve further research. Based on the abovementioned analysis, we expected that a high level of transformational leadership may lead to a decrease in employees' task performance after an inflection point.

In fact, Howell and Avolio pointed out that the "dark side" of transformational leadership has been largely ignored, and it could lead to destructive outcomes in any organization (Howell and Avolio 1992). Researchers and practitioners should focus more on its negative effects (Burke 2006; Villiers 2014; Walton 2014). Transformational leaders who have great personal charm set a good example and help increase the receptivity of followers to their task (Bass 1985; Kuhnert and Lewis 1987; Wang et al. 2005). But this high charisma level also leads to potential hubris, boastfulness, greed for power and success, self-centeredness and a feeling of superiority (Villiers 2014; Walton 2014). Bass noted that transformational leaders have strong authoritarian tendencies related to excessive self-glorification and are unaccepting of criticism in order to maintain their perfect image (Bass and Avolio 1990). That clearly reflects that they tend to overestimate their own value but undervalue that of their followers' (Bass 1999). This feature may also shift the focus of transformational leader from supporting followers to enhancing their own public image regardless of employees' and organizations' benefits (Resick et al. 2009). Likewise, transformational leaders' over-confident, excessive pursuit of power and superiority could limit the effectiveness of transformational leadership on followers' performance (Walton 2014). In addition, this is consistent with Eisenbeiss and Boerner's (2013) contention that transformational leadership increases followers' dependency on their leader because of their charisma. Employees depend on a leader's guidance and inspiration and expect to receive high identity. The situation can be compared to children who need parents' protection and security. Transformational leaders become idols and role models, whereby employees have high emotional attachment to them. As a result, followers strongly seek the leaders' recognition and express 
unconditional obedience to leaders, both of which inhibit their creativity (Basu and Green 1997). Further, followers have feelings of loss which reduce their engagement and willingness to perform tasks as a result of the absence of transformational leaders.

Too much concern and consideration from transformational leadership can increase instrumental costs including a low level of employees' goal achievements and task performance (Ames and Flynn 2007), neglecting tasks while spending more time socializing (Fleishman 1995) and even reducing their workload through the relational ties with their leaders. Providing positive feedback for employee performance may also ultimately undermine the goal (Kohn 1999). Kohn (2001) argued that this type of feedback hinders employees' good behaviors and performance in the long run. Encouragement and praise make employees more prone to performing simple tasks in order to maintain positive comments (Kohn 1999). They intend to finish fewer tasks to get attention and care from leaders. Kohn (2001) found that individuals who are rewarded for performing a creative task well tend to stumble at the next task. Alternatively, individualized consideration from leaders leads to followers experiencing greater psychological stress. Conversely, followers have a moral obligation to pay back according to the principle of reciprocation. Actually, perceived individualized consideration is also a mark of favoritism and inequity which can lead to relationship deterioration between leaders and followers.

Inspirational motivation, as one of the core dimensions of transformational leadership, means reshaping followers' values, attitudes and aspirations to achieve the organization's shared vision (Conger et al. 2000). Although organizations' interests are aligned with individuals' principles, it is undeniable that there is a potential conflict between the self-interest of employees and efforts for the greater benefits for organizations. The process of achieving an organization's goals could inevitably damage followers' self-interests. Poor task performance of employees is an expression of venting their dissatisfaction because their own interests are not sufficiently satisfied. Employees may also manifest their disappointment in frequent red lights of organizational vision.

Transformational leadership emphasizes followers' potential development and innovative consciousness rather than directly taking advantage of existing values of employees (Mills and Ungson 2003). However, too many transformational behaviors of leaders can lead to unexpected consequences such as overly empowering behaviors of leaders (Lee et al. 2016). Solving problems by themselves not only requires more time and energy seeking ways to conquer difficulties encountered in the process of work, but also leads to decreased efficiency in fulfilling core tasks (Mills and Ungson 2003). More and more unmotivated employees materialize and their willingness to exert effort on task performance decreases because of the absence of oversight from transformational leaders, especially when facing uninteresting or unimportant tasks. Additionally, higher autonomy and greater responsibility may lead to additional burdens such as high standards of performance, more task allocations and expression of ideas. Then, the cost of "stimulating potential" is possibly role ambiguity, role conflict, role overload and higher work stress (Spector et al. 1988), all of which hinder employees to achieve optimal outcomes in their task performance (Gilboa et al. 2008). Employees' cognition and behaviors and even the normal mode of work can be constantly changing based on a transformational leader's expectations. The influence of constantly changing the rhythm of work is directly 
embodied in the reduction of task performance (Summers et al. 1993). Taking these findings and reasonings together, we hypothesize as follows:

Hypothesis 1: The relationship between transformational leadership and task performance is characterized by an inverted $U$-shaped relationship where transformational leadership positively impacts employee task performance to a specific point (inflection point); Beyond this point the influence of transformational leadership on employee task performance declines.

\section{Proactive personality as a moderator}

Productivity or validity of transformational leadership is not consistent but depends on followers with different personality characteristics (Gong et al. 2009; Yun et al. 2005). According to the major premise of social cognitive theory, human action not only results from the surrounding environment but also from personality and cognition. Weak disposition characteristics of people can be compensated for by context-related cues and personality traits also play an important role in behavioral decisions (Bandura 1999). Leadership, as a shaping-the-working-context variable, takes compensatory effect for cognitive attitudes and behaviors of followers with particular traits (Howell and Avolio 1993; Judge et al. 2000; Judge and Piccolo 2004; Lord et al. 1986; Yukl 1989). For instance, Kark et al. (2003) pointed out that transformational leadership can promote greater innovation in employees with lower levels of proactive character orientation. In addition, Lepine and Van Dyne (1998) indicated that individuals with low self-efficacy may be more prone to influence by favorable situations. Similarly, desired individual personality characteristics may also compensate for the situation in a particular workplace. Grant and Sumanth (2009) found that employees with high intrinsic motivation maintain high performance even if supervisors are not favorable. Therefore, employees with certain personality traits better adapt to various degrees of transformational leadership than others (Ford and Fottler 1996).

Proactive personality, as a stable disposition personality trait, states that people with higher proactive personality are relatively unconstrained by contextual forces, and that they identify opportunities, act on them, show initiative, and strive to bring about meaningful change (Crant 2000). This construct is rooted in interactionism, which argues that situations are a function of the person as the person's behavior is a function of the situation (Bowers 1973). In this research, we assume that proactive personality of employees would moderate the curvilinear relationship between transformational leadership and task performance. Specifically, transformational leadership, when it is in middle and low degrees, has a greater positive effect on task performance when employees possess a low level of proactive personality. Otherwise, excessive transformational leadership has a less negative effect on task performance when employees hold a high level of proactive personality. In sum, the person, the external environment, and behavior continuously influence one another (Bandura 1986). The influence of proactive personality of employees and transformational leadership are mutually complementary.

Robust evidence has demonstrated that proactive personality is strongly relevant to desired outcomes such as work engagement (Sonnentag 2003), in-role performance 
(Fuller et al. 2006; Thompson 2005), and career success (Chan 2006; Seibert et al. 1999). Proactive people tend to maintain a strong sense of responsibility, search for opportunities to act, search for information and resources actively, and have strong needs for achievement and growth (Bateman and Crant 1993). Further, employees with a proactive personality would expend more effort to acquire new skills and knowledge and have more personal resources and personal achievements such as self-efficacy, self-regulation and career development (Bertolino et al. 2011). Studies in personality indicate that individuals with a high level of proactive personality have more potential productivity benefits due to being self-starters, and having change orientation and future-focused tactics in the pursuit process (Parker et al. 2010). Specifically, compared with employees who are not proactive, employees with a proactive personality invest more self-initiated effort in setting a proactive goal and make proactive goals a reality regardless of whether the external situations are good or bad. In particular, when employees are in a challenging situation, the validity of a proactive personality is more important. Accordingly, they seize opportunities, anticipate problems and make things happen utilizing a "decisive" response pattern to the external environment.

Employees with high proactive personalities might perform better than an employee with a less proactive personality when leaders are highly transformational. At low levels of transformational leadership, employees with high proactive personality may perceive insufficient circumstances or conditions for self-development, self-growth and self-achievement. Accordingly, they expend additional effort to identify various opportunities and search for important information from other contextual factors rather than merely from leaders, which does not lead to immediate effects on task performance because of their high level of investment in other aspects of organizational outcomes (Fuller and Marler 2009; Li et al. 2010; Seibert et al. 2001). Facing high levels of their leaders' transformational leadership such as a high degree of work arrangement, sufficient development resources and an attractive shared vision (Avolio et al. 1999; Howell and Avolio 1993; Judge and Piccolo 2004), it can be regarded as a favorable and challenging situation to employees with high proactive personality because of their higher level self-goals, self-efficacy and self-responsibility (Felfe and Schyns 2006; Lim and Ployhart 2004). In other words, their self-starting, orientation change and future-focused tactics are especially effective in such situations (Parker et al. 2010). Their improving performance is influenced by support from external conditions and resources and by their internal personality, motivation and ability (Hurtz and Donovan 2000; Judge and Ilies 2002). Employees who have a proactive personality would actively engage in developing their skills through building networks and possessing resources, expressing their needs clearly, and identifying the value and behavior orientation of transformational leadership. Proactive employees can improve their task performance dominated by strong intrinsic motivation even if a high level of transformational leadership brings out negative aspects.

In contrast, performance behaviors of employees with a low level of proactive personality are more likely to induce outside beneficial context clues (Abele and Spurk 2009). On the one hand, when leaders begin to perform transformational leadership such as providing personal attention based on needs, provision of resources to overcome problems and encouragement of performance (Stone et al. 2004), employees with a low proactive personality would possess advantageous resources and support in finishing work 
tasks. Therefore, under the influence of transformational leadership, they can overcome work obstacles and improve work efficiency easily (Judge et al. 2005; Kim et al. 2009). On the other hand, employees with a low proactive personality are likely to increase their perceptions of role overload and stress beyond their working range, intentional effort, and personal ability, and even be repelled by leaders' attention when leaders participate in more transformational behaviors such as offering a high degree of trust to employees' performance, frequent interactive communication, and strong stimulation of innovation and creativity (Bunderson and Sutcliffe 2003; Dweck and Leggett 1988; Vandewalle et al. 1999). Similarly, several empirical studies illustrate that an employee with a less proactive personality is prone to be satisfied with the status quo, "muddle along" and devote less energy to work (Bunderson and Sutcliffe 2003; Fuller et al. 2006; Thompson 2005). In sum, we hypothesize as follows:

Hypothesis 2: Employee proactive personality positively moderates the relationship between transformational leadership and employee task performance. That is, task performance diminishes later for higher proactive personality compared to lower proactive personality. Transformational leadership has a greater positive impact on task performance when employees have a low level of proactive personality.

\section{Study 1}

Methodology

Procedure and sample

The participants are drawn from 7 companies in the manufacturing, telecommunications, and hotel industries distributed in northern area of China, including 3 five-star hotels, 2 chemical fiber factories and 2 communication service suppliers. In the present study, we use samples from multiple industries which avoids contextual constraints associated with any particular organization (Johns 2001). In addition, the design of multiple-source data also reduces less common method bias. In the survey process, we first contacted the directors of these companies' human resources departments to request their assistance and consent to participate in this survey by means of telephone, and then requested them to set up two WeChat groups of immediate supervisors and subordinates. Each subordinate had only one immediate supervisor. Additionally, we prepared two detailed operations manuals, including steps and screenshots in order to make participants aware of how to complete the questionnaires online. Participants were told that the questionnaire was for academic research. In additional, they were also informed of the confidentiality of their responses. The completed questionnaires were collected by the researchers via WeChat, a widely used instant communication tool in China, in order to alleviate participants' potential concern about the exposure of their answers. Employees opened the questionnaires designated for subordinates to start the answering process. Then each employee received a unique pairing code that we allocated when they finished the questionnaire, and there were notified to send the pairing code to their immediate supervisors. According to this pairing code, supervisors opened the supervisor questionnaires to complete them.

The survey used the time-lagged design. The data were collected at two points of time, with a three-month interval. During Part 1, the measure of transformational 
leadership, proactive personality and demographic information was completed by subordinates; we received 308 questionnaires which could be used in subsequent analysis. During Part 2 (3 months later), the measures of employees' task performance was completed by immediate supervisors. After deleting the questionnaires with unmatched leader-employee pairs and incomplete answers, 209 supervisor-subordinate dyads were used in the present study, yielding a 59.7\% response rate. Specifically, 79 samples came from the hotel industry, 66 samples were from chemical fiber factories and 64 participants worked in the telecommunication industry. The average age of employees in our sample $(n=209)$ was 28.63 years old, and $98(46.89 \%)$ were males. 60.47 (in months) was their average organizational seniority. $7.2 \%$ of them had a master's degree or higher, $59.8 \%$ of them had a bachelor's degree, and $21.5 \%$ of them had graduated from college.

\section{Measures}

Prior to implementing the survey, to ensure meaning equivalence between English and Chinese, first we selected a back-translation (Brislin 1980) process to design the Chinese version of this questionnaire. All measures adopted in the research were translated from English to Chinese by a bilingual researcher, and then the responses were translated back into English.

\section{Transformational leadership}

Transformational leadership was measured with 14 items from Kirkman et al. (2009). The questionnaire generated scores based on following four dimensions: charismatic influence (e.g., "Provides a good model for me to follow"), individualized consideration (e.g., "Acts without considering my feeling"), inspirational motivation (e.g., "Has a clear understanding of where we are going") and intellectual stimulation (e.g., "Has stimulated me to rethink the way I do things"). Responses ranged from 1 (Strongly disagree) to 7 (Strongly agree). The Cronbach's alpha for this complete scale was 0.948 .

\section{Proactive personality}

To measure proactive personality, we used the 6-item scale developed by Bateman and Crant (1993). Items are on a 5-point Likert scale, ranging from 1 (disagree) to 5 (agree). Sample items included "If I see something I don't like, I fix it" and "No matter what the odds, if I believe in something I will make it happen." The Cronbach's alpha for the complete scale was 0.751 .

\section{Task performance}

We assessed task performance using 11-item scale developed by Tsui et al. (1997). The direct leader assessed the subordinates' task performance on a 7-point Likert scale. Responses ranged from 1 (strongly disagree) to 7 (strongly agree). Sample items were "Employee's quantity of work is higher than average" and "Employee's standards of work quality are higher than formal standards for this job." In this research, the Cronbach's alpha for the complete scale was 0.972 . 


\section{Control variables}

We controlled for some pivotal variables such as employees' demographic variables included gender, organizational seniority, age, and education level that could affect the result. These variables were controlled in the process of data analysis. Prior research has suggested that those variables were related to task performance (Carter et al. 2013; Chan et al. 2013; Maslyn and Uhl-bien 2001). Gender as a dichotomous variable was measured and coded as 1 for male and 0 for female. The measure of organizational seniority was the number of months a participant had been in the current job, and age was evaluated in years. Education level was viewed as a continuous variable which encoded ranging from 0 (junior high school or below) to 7 (master's degree or higher).

\section{Analysis and results}

To avoid the existing possibility of common method bias in the current study, we adopted the multiple-source data and time-lagged design following recommendations proposed in the literature by Podsakoff et al. (2012). In addition, the confidentiality of participants' responses and personal information was strictly maintained. Harman's one-factor analysis demonstrated that no single factor occurs and no single factor accounts for $>50 \%$ of the variance of all the relevant items. Based on the above, the results indicate that a common method bias is not a concern in the research.

\section{Confirmatory factor analyses}

Before hypotheses testing, we first conducted CFA (Mplus) procedures to verify the distinctiveness of the three variables included in the present research: transformational leadership, proactive personality and task performance. According to sub-dimension of transformational leadership, parceling was used. As is shown in Table 1, the baseline model (3-factor model) fits the data well $\left(\chi^{2} / d f=2.177, \mathrm{CFI}=0.945, \mathrm{TLI}=0.938\right.$, RMSEA $=0.075$, SRMR $=0.049)$. Compared with Model A $\left(\chi^{2} / d f=3.311\right.$, CFI $=0.891$, $\mathrm{TLI}=0.878, \mathrm{RMSEM}=0.105, \mathrm{SRMR}=0.093)$, Model $\mathrm{B}\left(\mathrm{x}^{2} / d f=3.384, \mathrm{CFI}=0.888\right.$, TLI $=0.874$, RMSEM $=0.107, \mathrm{SRMR}=0.094)$ and Model $\mathrm{C}\left(\mathrm{x}^{2} / d f=6.912, \mathrm{CFI}=0.721\right.$, TLI $=0.688$, RMSEM $=0.168$, SRMR $=0.125)$, the baseline model, namely, the 3 -factor model, offers a significant improvement. As such, we selected the three constructs for our analyses.

\section{Descriptive analysis}

Table 2 presents the means, standard deviations, correlations, and alpha coefficients for the variables used in the study. All variables have reasonable reliabilities, with

Table 1 Comparison of measurement models

\begin{tabular}{lllllll}
\hline Model & Factor & $X^{2} / \mathrm{df}$ & CFI & TLI & RMSEA & SRMR \\
\hline The baseline model & TL, PP, TP & 2.177 & 0.945 & 0.938 & 0.075 & 0.049 \\
Model A & $T L+P P, T P$ & 3.311 & 0.891 & 0.878 & 0.105 & 0.093 \\
Model B & $T L, P P+T P$ & 3.384 & 0.888 & 0.874 & 0.107 & 0.094 \\
Model C & $T L+P P+T P$ & 6.912 & 0.721 & 0.688 & 0.168 & 0.125 \\
\hline
\end{tabular}

CFI comparative fix index, TLI Tucker-Lewis index, RMSEA root mean square error approximation, SRMR standardized root mean square residual, $T L$ transformational leadership, $P P$ proactive personality, $T P$ task performance 
Table 2 Means, standard deviations, correlations, and reliabilities

\begin{tabular}{llllllllll}
\hline Variable & Mean & SD & 1 & 2 & 3 & 4 & 5 & 6 & 7 \\
\hline Age & 28.63 & 5.95 & & & & & & \\
Gender & 0.47 & 0.50 & $0.138^{*}$ & & & & & \\
Seniority & 60.47 & 72.42 & $0.909^{* *}$ & 0.100 & & & & \\
Education & 4.52 & 1.04 & -0.061 & -0.130 & & & & \\
$T L$ & 4.28 & 1.32 & -0.072 & 0.074 & -0.067 & -0.107 & $\mathbf{0 . 9 4 8}$ & & \\
$P P$ & 3.55 & 0.67 & $-0.213^{* *}$ & -0.103 & $-0.194^{* *}$ & 0.042 & 0.111 & $\mathbf{0 . 7 5 1}$ & \\
$T P$ & 4.78 & 1.25 & 0.002 & 0.082 & 0.014 & 0.009 & $0.536^{* *}$ & 0.108 & $\mathbf{0 . 9 7 2}$ \\
\hline$n=209 ;{ }^{*} p<0.05^{* *} p<0.01$ (two-tailed); Cronbach's alpha in bold; Gender $(0=$ female, $1=$ male $)$ & &
\end{tabular}

Cronbach's alpha coefficients of 0.70 or higher. Based on the bivariate associations, transformational leadership is statistically significantly correlated to task performance.

\section{Difference tests}

In consideration of the case that our data came from different industries and organizations, we need to conduct an aggregation test in order to ensure the validity of multilevel modeling analysis. Specifically, the aggregation test was to examine whether employees in the different organizations and industries were significantly differentiated. We first adopted one-way ANOVA analysis and the results $(F(6,202)=1.687, p>0.05$; $F(2,202)=1.737, p>0.05)$ demonstrates that there are no significant variations of task performance in different organizations and industries, respectively. We also tested inter-rater reliability among members of different organizations and industries by calculating intra-class correlation coefficients (ICC), respectively, where $\mathrm{ICC}_{(1)}$ represents the ratio of between-group variance to total variance, and $\mathrm{ICC}_{(2)}$ represents the reliability of the group mean (Bliese 2000). The results of intra-class correlations among organizations and industries are $\left(\mathrm{ICC}_{(1)}=0.02, \mathrm{ICC}_{(2)}=0.41\right)$ and $\left(\mathrm{ICC}_{(1)}=0.01, \mathrm{ICC}_{(2)}=\right.$ 0.42). The acceptable standard of $\mathrm{ICC}_{(1)}$ and $\mathrm{ICC}_{(2)}$ are $\mathrm{ICC}_{(1)}>0.05$ and $\mathrm{ICC}_{(2)}>0.5$ (Klein et al. 2000). Therefore, according to those unsupportive indices, it is infeasible to use the HLM model for analysis.

\section{Hypotheses testing}

In order to test our hypotheses, we need to specify and estimate the following regression models. First, we tested the possibility of non-linearity $(\mathrm{H} 1)$ in the relationship between transformational leadership and task performance as follows:

$$
\begin{aligned}
& T P_{i}=\beta_{0}+\beta_{1} T L_{i}+\mu \mathrm{e}_{i}, \\
& T P_{i}=\beta_{0}+\beta_{1} T L_{i}+\beta_{2} T L^{2}{ }_{i}+\mu \mathrm{e}_{i},
\end{aligned}
$$

where $T L^{2}{ }_{\mathrm{i}}=T L_{\mathrm{i}} \times T L_{\mathrm{i}}$, supporting the inverted U-shaped relationship between transformational leadership and task performance must satisfy the following conditions: $\beta_{0}$ and $\beta_{1}>0 ; \beta_{2}<0$.

Then, we tested our second hypothesis for the role of proactive personality in moderating the relationship between transformational leadership and employee task performance. Based on the approach of Baron and Kenny (1986), we added the moderator variable (proactive personality) to Eq. (2), as follows: 


$$
T P_{i}=\beta_{0}+\beta_{1} T L_{i}+\beta_{2} T L^{2}{ }_{i}+\beta_{3} P P_{i}+\beta_{4}\left(P P_{i} \times T L_{i}\right)+\beta_{5}\left(P P_{i} \times T L_{i} \times T L_{i}\right)+\mu \mathrm{e}_{i},
$$

where $\beta_{\mathrm{i}} \mathrm{s}$ are regression coefficients of equations and $\beta_{4}$ and $\beta_{5}$ are the coefficients of the interaction terms, respectively. If either $\beta_{4}$ and/or $\beta_{5}$ are statistically significant, H2 is supported. Eq. (1) tests the direct and linear relationship between transformational leadership and employees' task performance. Eq. (2) signifies the curvilinear relationship between transformational leadership and employees' task performance (H1). Eq. (3) tests the moderating role of proactive personality on the transformational leadership and employees' task performance (H2). This method is widely used to assess curvilinear relationships in management research (Burnett et al. 2015; Lechner et al. 2010; Zettler and Lang 2015).

We followed hierarchical regression analysis using SPSS software, and the independent variables (transformational leadership) and proactive personality variables were all mean-center for testing the interaction effects to reduce potential multicollinearity problems (Aiken and West 1994). Table 3 presents the results of the regression analyses.

Hypothesis 1 suggests that the relationship between transformational leadership and task performance is U-shaped. We used Janssen's (2001) 3-step procedure. In the first step, we entered the four control variables; namely, gender, age, seniority and education (Model 1). In the second step, transformational leadership was included (Model 2). In the third step, transformational leadership squared was included (Model 3). As shown

Table 3 Hierarchical regression analysis for employee task performance

\begin{tabular}{|c|c|c|c|c|c|}
\hline \multirow[t]{2}{*}{ Variable } & \multicolumn{5}{|l|}{$T P$} \\
\hline & Model 1 & Model 2 & Model 3 & Model 4 & Model 5 \\
\hline \multicolumn{6}{|l|}{ Step 1} \\
\hline Age & -0.019 & -0.013 & -0.004 & 0.000 & -0.007 \\
\hline Gender & 0.221 & 0.124 & 0.036 & 0.050 & 0.060 \\
\hline Seniority & 0.002 & 0.002 & 0.001 & 0.001 & 0.001 \\
\hline Education & 0.030 & 0.099 & 0.032 & 0.025 & 0.059 \\
\hline \multicolumn{6}{|l|}{ Step 2} \\
\hline$T L$ & & $0.678^{* *}$ & $0.515^{* *}$ & $0.375^{* *}$ & $0.506^{* *}$ \\
\hline \multicolumn{6}{|l|}{ Step 3} \\
\hline$T L^{2}$ & & & $-0.268^{* *}$ & $-0.281^{* *}$ & $-0.273^{* *}$ \\
\hline \multicolumn{6}{|l|}{ Step 4} \\
\hline$P P$ & & & & 0.115 & $0.233^{*}$ \\
\hline \multicolumn{6}{|l|}{ Step 5} \\
\hline$T L \times P P$ & & & & & $0.439^{*}$ \\
\hline \multicolumn{6}{|l|}{ Step 6} \\
\hline$T L \times T L \times P P$ & & & & & -0.083 \\
\hline$R^{2}$ & 0.009 & 0.298 & 0.342 & 0.350 & 0.374 \\
\hline Change in $F$ & 0.441 & $17.211^{* *}$ & $17.469^{* *}$ & $15.432^{* *}$ & $13.194^{* *}$ \\
\hline Change in $R^{2}$ & 0.009 & 0.289 & 0.044 & 0.008 & 0.008 \\
\hline
\end{tabular}

Entries are standardized regression coefficients

$T L$ transformational leadership, $T L^{2}$ transformational leadership squared, $P P$ proactive personality, $T P$ task performance $n=209 ;{ }^{*} p<0.05{ }^{* *} p<0.01$ (two-tailed) 
in Table 3 (Model 3), the squared term for task performance is also significant ( $\beta=-$ $0.268, p<0.01) . \beta_{2}$ is statistically-significant and satisfies the a priori inverted U-shaped relationship condition, with $\beta_{2}<0$ in the equations. Thus, Hypothesis 1 is supported; namely, there is an inverted U-shaped relationship between transformational leadership and task performance (see Fig. 1).

Hypothesis 2 predicts that a proactive personality moderates the curvilinear relationship between transformational leadership and task performance. In Model 5, proactive personality, its interaction with transformational leadership and the product of proactive personality and transformational leadership squared were all included. The parameter estimate of $\beta_{5}$ is not statistically significant, while the parameter estimate of $\beta 4$ is statistically significant; thereby satisfying the condition for the moderation hypothesis. Thus, Hypothesis 2 is supported. In additional, in order to clearly reveal the moderating effect of employees' proactive personality on the inverted U-shaped relationship between transformational leadership and task performance, we plotted the interaction in Fig. 2 and calculated the simple slopes ( $-1 \mathrm{SD} ;+1 \mathrm{SD}$ ) using the Johnson-Neyman technique developed by Bauer and Curran (2005). The result of the simple slopes test is that simple slope is not significant from 0 when moderating variable-proactive personality is within its change range.

As shown in Fig. 2, we verified the interaction effect of proactive personality, while transformational leadership and employee task performance has a non-monotonic relationship across proactive personality; the inflection point where transformational leadership starts to have a negative effect on task performance is found at higher levels of transformational leadership for those with a high proactive personality than those with a low proactive personality. Overall, Hypothesis 2 is supported.

\section{Study 2}

Study 2 was conducted to test all of our hypotheses again, to replicate the findings of Study 1 in a bank context, and corroborate our results across studies (Mathison 1988;

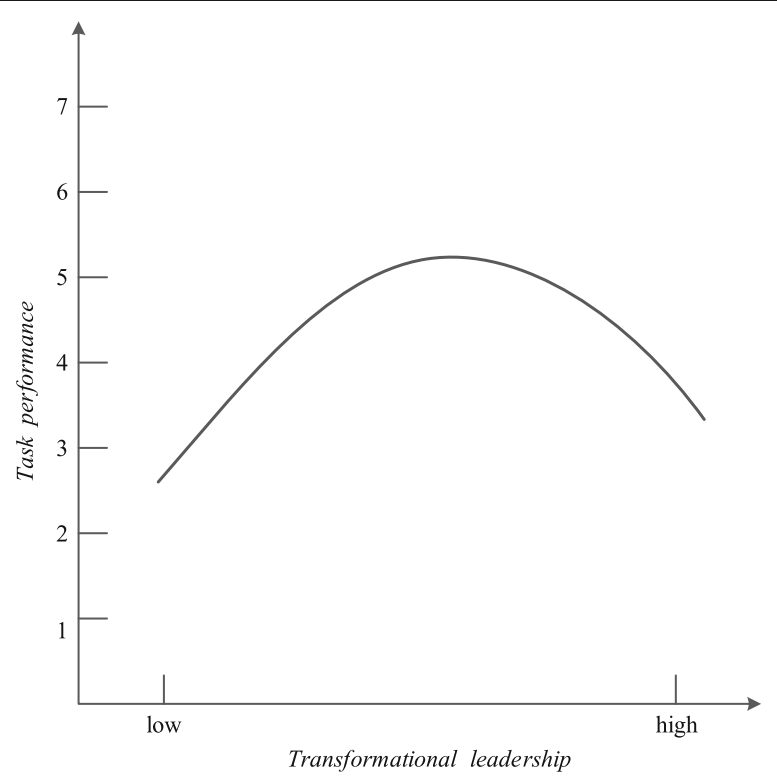

Fig. 1 Curvilinear relationship between transformational leadership and task performance 


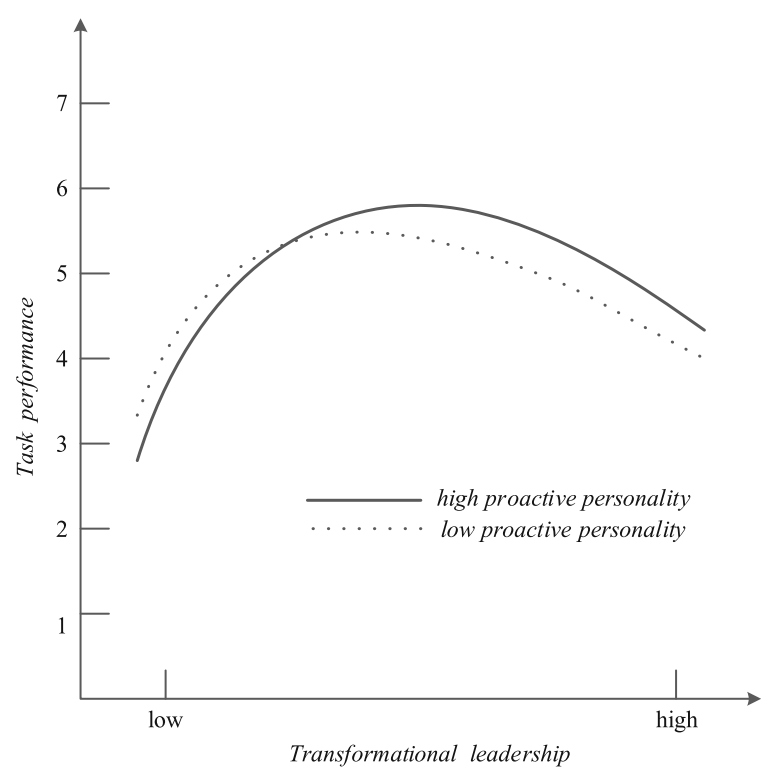

Fig. 2 Moderating effects of proactive personality on transformational leadership and task performance

Webb et al. 1966). We hope our findings provide more confidence in the interpretation of these results and their robustness.

\section{Methodology}

\section{Participants and procedure}

In Study 2, 168 employees with only one immediate supervisor, working in the Bank of China, Qinhuangdao Branch, were recruited. Fifty-five immediate supervisors of those employees also participated in the survey. Electronic survey data collection occurred in two waves. In the first wave, we collected demographic information, transformational leadership and a measure of proactive personality from employees. In the second wave, which began 2 weeks following the end of the first wave, we collected demographic information and employees' task performance from supervisors. In the survey process, the purpose of the survey being to commit to academic research, confidentiality of personal information and answers, and operation manuals were all expounded upon in detail within a WeChat group. In addition, we provided some rewards in the WeChat group to encourage participants to fill out the questionnaires. Employees opened the subordinate questionnaires to start their answers. Then, each employee received a unique pairing code that we allocated when they finished the questionnaires, and their immediate supervisors were notified of the pairing code of each employee. Supervisors could open the supervisor questionnaires to complete questions after receiving the pairing code from their subordinates.

As a result, 139 supervisor-subordinate data were gained across the two waves. For subordinates participating in the study, 82 (59\%) were women. The average age of employees was approximately 30 years old. The average tenure with the organization was 70.46 months and the average tenure within the career was 82.45 months. $88.5 \%$ of them had a college degree or higher. 
Measures

Study 2 used scales and items also used in Study 1.

\section{Control variables}

Similar to Study 1, we controlled for employees' age, gender, organizational tenure, and level of education. Additionally, we controlled for career tenure. Gender was measured and coded as 1 for male and 0 for female. The measure of organizational tenure was the number of months a participant had been in the current organization and career, and age was evaluated in years. Education was viewed as a continuous variable which was encoded ranging from 1 (junior high school or below) to 5 (doctoral degree).

\section{Analysis and results}

The result of Harman's single factor test shows that no single factor emerges and no single factor accounts for $>50 \%$ of the variance of all the relevant items. Specifically, an exploratory factor analysis of all items explains $75.90 \%$ of the total variance and the largest factor accounts for only $38.17 \%$ of the variance. Therefore, common method bias is not a major question in the study.

Second, we conducted a series of confirmatory factor analyses in order to test whether the discriminate validity of constructs in this study was adequate. The results are shown in Table 4 . The three-factor model fits the data well, $\chi^{2} / \mathrm{df}=1.865, \mathrm{CFI}=$ 0.922, $\mathrm{TLI}=0.915$, RMSEA $=0.079$ and SRMR $=0.062$.

Third, descriptive statistics, including observed variable means, standard deviations, correlations and reliability coefficients, are presented in Table 5. Transformational leadership is positively related to task performance. Cronbach's alpha coefficients of transformational leadership, proactive personality and task performance are 0.937, 0.819 and 0.969 respectively, which signifies that all of them have good reliability.

Finally, the results of regression analyses are shown in Table 6. As shown in Table 6, the coefficient for the transformational leadership quadratic term is significant $(\beta=-0.279, p$ $<0.05$, Model 3). Thus, there is a curvilinear relationship between transformational leadership and employee task performance. In addition, Fig. 3 shows an inverted U-shaped relationship between transformational leadership and employee task performance. Thus, Hypothesis 1 is supported.

Then, we tested the moderating influence of employees' proactive personality on the relationship between transformational leadership and task performance. In Model 5, we found that the squared interaction term $T L^{2}{ }_{\mathrm{i}} \times P P_{\mathrm{i}}$, and the interaction term $T L_{\mathrm{i}} \times P P_{\mathrm{i}}$ are both statistically significant; thereby satisfying the condition for the moderation hypothesis (H2). Hypothesis 2 is supported. Furthermore, we performed simple slope analysis, with the result of plotting interaction shown in Fig. 4.

Table 4 Comparison of measurement models

\begin{tabular}{lllllll}
\hline Model & Factor & $X^{2} / \mathrm{df}$ & CFI & TLI & RMSEA & SRMR \\
\hline The baseline model & $T L, P P, T P$ & 1.865 & 0.922 & 0.915 & 0.079 & 0.062 \\
Model A & $T L+T P, P P$ & 5.630 & 0.583 & 0.544 & 0.183 & 0.264 \\
Model B & $T L+P P+T P$ & 6.070 & 0.542 & 0.501 & 0.191 & 0.270 \\
\hline
\end{tabular}


Table 5 Means, standard deviations, correlations, and reliabilities

\begin{tabular}{lllllllllll}
\hline Variable & Mean & SD & 1 & 2 & 3 & 4 & 5 & 6 & 7 \\
\hline Age & 30.35 & 7.858 & & & & & & & \\
Gender & 0.41 & 0.494 & 0.157 & & & & & & \\
Organizational tenure & 70.46 & 77.66 & $0.772^{* *}$ & $0.178^{*}$ & & & & & \\
Career tenure & 82.45 & 91.83 & $0.877^{* *}$ & 0.160 & $0.831^{* *}$ & & & & \\
Education & 2.99 & 0.518 & $-0.550^{* *}$ & $-0.187^{*}$ & $-0.504^{* *}$ & $-0.585^{* *}$ & & & \\
$T L$ & 5.24 & 1.323 & 0.037 & 0.101 & 0.027 & -0.003 & 0.001 & $\mathbf{0 . 9 3 7}$ & \\
$P P$ & 3.78 & 0.800 & $0.197^{*}$ & $0.184^{*}$ & 0.144 & 0.130 & $-0.220^{* *}$ & $0.399^{* *}$ & $\mathbf{0 . 8 1 9}$ & \\
$T P$ & 5.81 & 1.188 & -0.012 & 0.137 & 0.143 & -0.060 & -0.003 & $0.340^{* *}$ & 0.148 & $\mathbf{0 . 9 6 9}$ \\
\hline
\end{tabular}

Notes. $\mathrm{N}=139 ;{ }^{*} p<0.05{ }^{* *} p<0.01$ (two-tailed); Cronbach's Alpha in bold; Gender ( $0=$ female $1=$ male)

\section{Discussion}

The main purpose of this study is to investigate the nature of the relationship between transformational leadership and employees' task performance. Our results suggest that the effects of transformational leadership are not a simple linear relationship but are more complicated; specifically, transformational leadership has an inverted U-shaped relationship with employees' task performance in the work space. This study is to question this conventional view of the positive relation between transformational leadership and task performance and develops the curvilinear association in the relationship mentioned above. After reaching an inflection point, the positive influence of transformational leadership diminishes. Furthermore, drawing upon social cognitive theory, we demonstrate that employees' proactive personality plays a statistically significant moderating role on the transformational leadership-task performance relationship.

Table 6 Hierarchical regression results on employee task performance

\begin{tabular}{|c|c|c|c|c|c|}
\hline Variable & Model 1 & Model 2 & Model 3 & Model 4 & Model 5 \\
\hline \multicolumn{6}{|l|}{ Step 1: Control variable } \\
\hline Age & 0.052 & 0.002 & 0.034 & 0.031 & 0.039 \\
\hline Gender & -0.115 & -0.084 & -0.086 & -0.085 & -0.065 \\
\hline Education & 0.002 & -0.011 & -0.066 & -0.064 & -0.037 \\
\hline Seniority3 & $-0.624^{* *}$ & $-0.579^{* *}$ & $-0.662^{* *}$ & $-0.660^{* *}$ & $-0.640^{* *}$ \\
\hline Seniority4 & $0.613^{* *}$ & $0.594^{* *}$ & $0.612^{* *}$ & $0.612^{* *}$ & $0.595^{* *}$ \\
\hline \multicolumn{6}{|l|}{ Step 2: Independent variable } \\
\hline$T L$ & & $0.313^{* *}$ & 0.094 & 0.102 & 0.018 \\
\hline \multicolumn{6}{|l|}{ Step 3: Quadratic term main effects } \\
\hline Transformational leadership squared $\left(T L^{2}\right)$ & & & $-0.279^{*}$ & $-0.282^{*}$ & $-0.286^{*}$ \\
\hline \multicolumn{6}{|l|}{ Step 4: Moderating variable } \\
\hline$P P$ & & & & 0.014 & -0.186 \\
\hline \multicolumn{6}{|l|}{ Step 5: Moderation effects } \\
\hline$T L X P P$ & & & & & $0.382^{* *}$ \\
\hline$T L^{2} \times P P$ & & & & & $0.495^{* *}$ \\
\hline$R^{2}$ & 0.144 & 0.240 & 0.268 & 0.268 & 0.316 \\
\hline Change in $F$ & $4.426^{* *}$ & $6.890^{* *}$ & $6.795^{* *}$ & $5.094^{* *}$ & $5.880^{* *}$ \\
\hline Change in $R^{2}$ & 0.144 & 0.096 & 0.028 & 0.000 & 0.048 \\
\hline
\end{tabular}

Notes. $\mathrm{N}=139 ;{ }^{*} p<0.05{ }^{* *} p<0.01$ (two-tailed) 


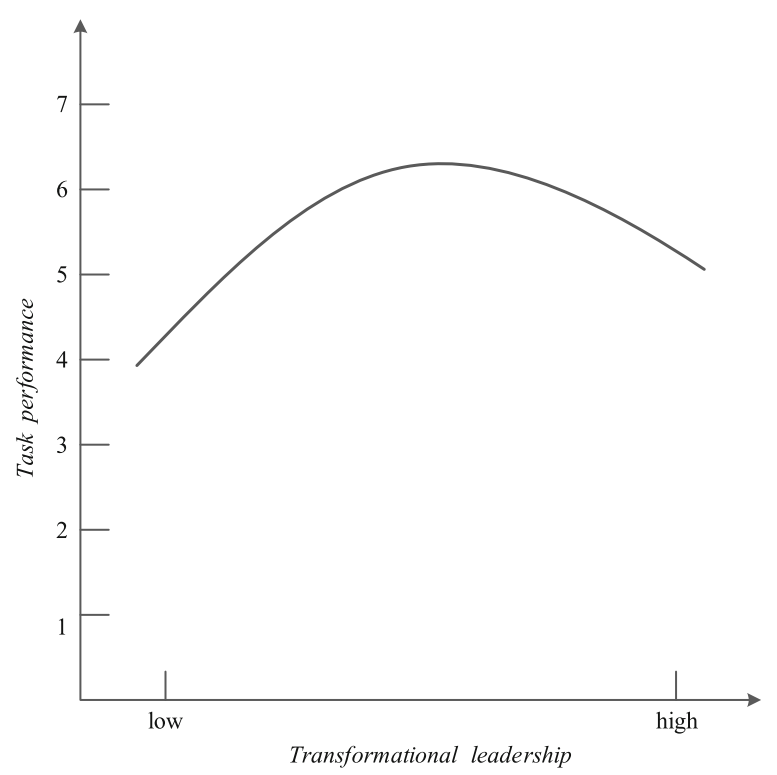

Fig. 3 Curvilinear relationship between transformational leadership and task performance

\section{Theoretical contributions}

The findings of this study contribute to the existing literature in at least three ways. Firstly, this paper extends the understanding about the role of transformational leadership on employee performance. We challenge the notion that transformational leadership, regarded as a desirable leadership style, leads to more ideal work outcomes (Aryee et al. 2012; Walumbwa et al. 2008; Wang et al. 2005). By adopting a paradox perspective, TMGT effect, and the principle of diminishing marginal utility, the study explains that the influence of transformational leadership on employee task performance is more complex than the simple linear relationship conventionally assumed in previous studies. A curvilinear relationship is uncovered in this study between transformational

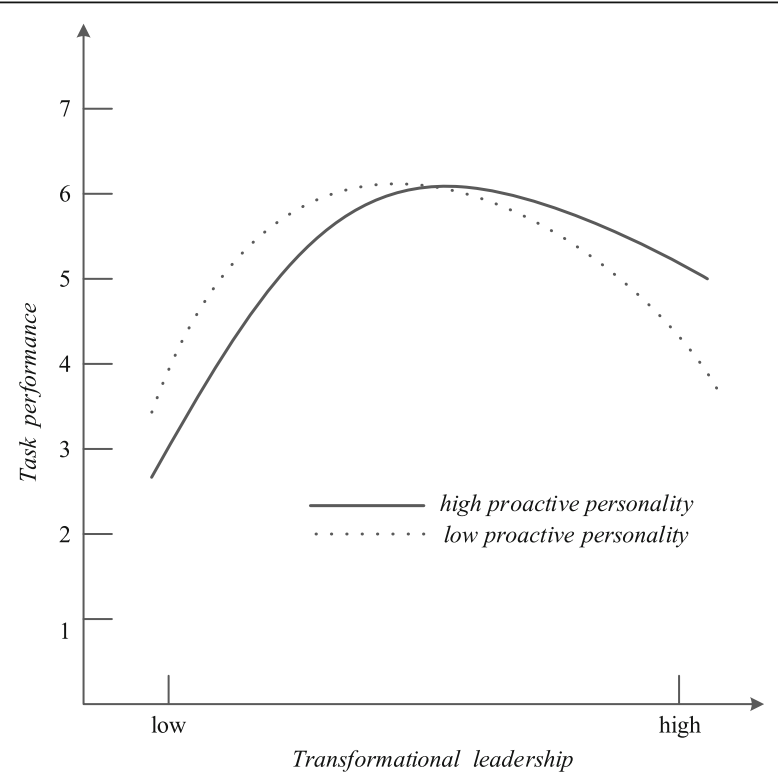

Fig. 4 Moderating effects of proactive personality on transformational leadership and task performance 
leadership and employee task performance. Paradox offers a novel and valuable perspective for examining the nature of leadership (Eisenhardt 2000; Lewis et al. 2000). Transformational leadership's two sides coexist, both angel and devil. Integrating the TMGT effect (Pierce and Aguinis 2013), and the principle of diminishing marginal utility, we clearly explain the paradoxical influence process of transformational leadership. This study also responds to the call that researchers should focus more on the negative effects of transformational leaders (Tourish and Pinnington 2002). In accordance with Edwards and Berry (2010), theories should contain greater specificity in order to make progress. The use of the TMGT effect and the principle of diminishing marginal utility in literature on transformational leadership expands and tests the applicative range of the principle of diminishing marginal utility and the TMGT effect in organizational management, respectively. Our findings also provide evidence that an intermediate level of transformational leadership may produce optimal and best task performance of employees.

Secondly, our study extends the transformational leadership approach by identifying the role of proactive personality in leadership effectiveness. Based on social cognitive theory, our study finds that proactive personality positively moderates the curvilinear relationship between transformational leadership and task performance. Employees with a high degree of proactive personality prefer a challenging situation, and better cope with a high degree of work arrangement, work load and sufficient resources under high levels of transformational leadership. Therefore, when employees have a higher level of proactive personality, the inflection point of the curvilinear relationship is delayed. The level of individual proactive personality needs to be considered as an important influential factor in predicting transformational leadership effectiveness and productivity; however, research which directly examines the interactional effects between transformational leadership and proactive personality on employees' performance outcomes is scare (Wang et al. 2011). In order to fill the gaps of previous research, we include employees' proactive personality as a moderator in our model. Thus, employee personality traits can play a critical role in practicing transformational leadership and follower characteristics should be understood before determining the level of transformational leadership.

Thirdly, in terms of predicting and improving employee performance research, the leadership research rarely recognizes meaningful individual differences among employees and the significant influence of leadership has been largely overlooked in previous studies of personality (Howell and Shamir 2005; Ostroff and Bowen 2016; Uhl-bien et al. 2004). The research, including most studies on leader-based effects for subordinates' attitudes and behaviors and follower-based effects for themselves, has emphasized one side of actors (leaders or followers themselves), concluding that it is valid. However, we respond to the repeated calls for focusing on followers' role in leadership research (Shamir 2007; Uhl-Bien et al. 2014) and focusing on leaderships' role in the follower personality literature (Ostroff and Bowen 2016). This study bridges the gap by integrating the effect of leadership and employees' personality on employees' task performance. Accordingly, our study directly examines the effects of interaction between transformational leadership and proactive personality on employee task performance. The results provide a deeper, richer portrait of organizational life-one that acknowledges the influence of individuals' trait on the individual behaviors, and the influence of 
leader on individual activities (Klein et al. 2000). This study is thus an extension of the research on task performance which is limited to a single visual angle that ignores influence from other factors.

\section{Practical implications}

Beyond theoretical contributions to the leadership literature, this study provides some meaningful practical suggestions. Firstly, this study indicates that the influence of transformational leaders on follower task performance could become negative upon exceeding a certain threshold. Therefore, transformational leadership is a mixed blessing for organizations. It would be beneficial for organizations to recognize the positive effects of transformational leadership as well as its negative aspects and to adopt the transformational leadership style with a balanced view. Maintaining balanced elements in transformational leadership such as distance and closeness with their followers, controlling work processing and making space for self-development is beneficial for employees' performance in the organizations (Zhang et al. 2015). Leaders with excessive transformational behaviors appear to cause additional role burden and psychological pressure on the employees. Accordingly, organizations should provide opportunities through which employees could communicate with their leaders and colleagues at social gatherings or other recreational activities. Similarly, it is advisable that organizations offer psychological counseling for employees, give several additional days off per month for relaxation, and encourage employees to pursue further self-development or self-actualization. Additionally, this study suggests that employees' proactive personality has a great influence on the cognition of transformational leadership behaviors. Consistent with evidence in personnel selection (Akgunduz et al. 2018), the selection of appropriate employees based on their proactivity appears to be effective for organizations. Managers need to consider employees' personality traits for leadership effectiveness and employees' personality characteristics should be matched with suitable leadership. Thus, organizations should design and develop scientific recruitment and selection procedures which take into consideration potential employees' personality traits.

\section{Limitations and further research}

Several limitations of this study should be noted. First, considering the design of cross-sectional research, our findings may not be able to completely explain the causality in the current study. Therefore, future research should utilize longitudinal data or adopt an approach called the design of experiments to ensure the results reflect causation clearly. Second, the study samples are selected by the convenience sampling method rather than random sampling because of the limitation of human, material and financial resources and other factors, although this method has been widely adopted by previous studies. Due to the possibility that the convenience sample may produce errors, future research can provide sufficient representative samples to further increase the credibility and universality of the conclusions. In addition, we collect data only from China and could thus not avoid country context constraints. Data sets from other countries, especially Western countries, will be needed to validate the universality of our study's results. Meanwhile, no significant difference is discovered among organizations and industries due to the small sample size ( 7 organizations and 3 different 
industries). Future research could also consider organization and industry as influential factors using multilevel analysis, and collect a greater number of samples from more organizations in different industries (Wen and Chiou 2009). Finally, this study only explores whether proactive personality moderates the relationship between transformational leadership and employee task performance. For greater breadth from both theoretical and empirical perspectives, future research can investigate the effect of work characteristics, employees' emotion or motivation, and organizational characteristics as boundary conditions on the performance expression of transformational leadership in order to understand profoundly behavioral outcomes implied in the influence process of transformational leadership. Similarly, considering that transformational leadership theories have been used to predict various organizational outcomes, the analytical framework may be extended to other outcomes, such as organizational citizenship behavior and employees' creativity. Future empirical research is needed to test the above assumptions.

\title{
Acknowledgements
}

We highly appreciate the valuable comments and suggestions from Dr. Lynda Song, and others in the seminar organized by the Business School of Renmin University of China in June 2018.

\section{Funding}

Funding for this research was provided by China's NSFC (71572170). The funding was used to support the necessary costs for completing this study, including on-site traveling, data analysis, proofreading, etc.

\section{Availability of data and materials}

Please contact author for data requests.

\section{Authors' contributions}

YCJ and CYS worked together by discussions on developing research questions and theoretical models. CYS proposed the preliminary research design and $\mathrm{YCJ}$ improved the research design by adding the moderator of proactive personality. NRR designed the questionnaire and YT improved it by adding more demographic information questions. FSJ collected the data and performed the data analyses. CYS wrote the first draft, NRR and YT improved dramatically the introduction and discussion sections. They worked together on the revision based on the comments of reviewers based on extensive discussions. All authors read and approved the final manuscript.

\begin{abstract}
Authors' information
Ms. Yashuo Chen is a Postgraduate in School of Economics and Management, Yanshan University, China. Her research mainly focuses on the organizational behavior and human resources management.

Ms. Ranran Ning is a Postgraduate in School of Economics and Management, Yanshan University, China. Her research mainly focuses on the organizational behavior and human resources management.

Ms. Tong Yang is a Postgraduate in School of Economics and Management, Yanshan University, China. Her research mainly focuses on the organizational behavior and human resources management.

Mr. Shangjun Feng is a Postgraduate in School of Economics and Management, Yanshan University, China. His research mainly focuses on the organizational behavior and human resources management.

Dr. Chunjiang Yang is a Professor and doctoral supervisor in the School of Economics and Management at Yanshan University in China. His academic interests mainly fall in organizational behavior and human resources management.
\end{abstract}

Competing interests

The authors declare that they have no competing interests.

\section{Publisher's Note}

Springer Nature remains neutral with regard to jurisdictional claims in published maps and institutional affiliations.

Received: 5 May 2018 Accepted: 6 November 2018

Published online: 06 December 2018

References

Abele, A. E., \& Spurk, D. (2009). The longitudinal impact of self-efficacy and career goals on objective and subjective career success. Journal of Vocational Behavior, 74(1), 53-62.

Ahmad, A., Asgari, A., Silong, A. D., \& Samah, B. A. (2008). The relationship between transformational leadership behaviors, organizational justice, leader-member exchange, perceived organizational support, Trust in Management and Organizational Citizenship Behaviors. European Journal of Social Sciences, 6(4), 140-151.

Aiken, L. S., \& West, S. G. (1994). Multiple regression: Testing and interpreting interactions. Evaluation Practice, 45(1), 119-120. 
Akgunduz, Y., Alkan, C., \& Gök, Ö. A. (2018). Perceived organizational support, employee creativity and proactive personality: The mediating effect of meaning of work. Journal of Hospitality \& Tourism Management, 34, 105-114.

Ames, D. R., \& Flynn, F. J. (2007). What breaks a leader: The curvilinear relation between assertiveness and leadership. Journal of Personality and Social Psychology, 92(2), 307-324.

Aryee, S., Walumbwa, F. O., Zhou, Q., \& Hartnell, C. A. (2012). Transformational leadership, innovative behavior, and task performance: Test of mediation and moderation processes. Human Performance, 25(1), 1-25.

Avolio, B. J., \& Bass, B. M. (1995). Individual consideration viewed at multiple levels of analysis: A multi-level framework for examining the diffusion of transformational leadership. Leadership Quarterly, 6(2), 199-218.

Avolio, B. J., \& Bass, B. M. (2002). Developing potential across a full range of leadership: Cases on transactional and transformational leadership. New York: Psychology Press.

Avolio, B. J., Bass, B. M., \& Jung, D. I. (1999). Re-examining the components of transformational and transactional leadership using the multifactor leadership. Journal of Occupational \& Organizational Psychology, 72(4), 441-462.

Avolio, B. J., Zhu, W., Koh, W., \& Bhatia, P. (2004). Transformational leadership and organizational commitment: Mediating role of psychological empowerment and moderating role of structural distance. Journal of Organizational Behavior, 25(8), 951-968.

Baer, M., \& Oldham, G. R. (2006). The curvilinear relation between experienced creative time pressure and creativity: Moderating effects of openness to experience and support for creativity. Journal of Applied Psychology, 91(4), 963.

Bandura, A. (1986). Social Foundations of Thought \& Action: A Social Cognitive Theory. Englewood cliffs: Prentice-Hall, Inc..

Bandura, A. (1999). Social cognitive theory of personality. In A. P. Lawrence \& P. J. Oliver (Eds.), Handbook of personality: Theory and research, (pp. 154-196). New York: Guilford Publications.

Barling, J., Loughlin, C., \& Kelloway, E. K. (2002). Development and test of a model linking safety-specific transformational leadership and occupational safety. Journal of Applied Psychology, 87(3), 488-496.

Baron, R. M., \& Kenny, D. A. (1986). The moderator-mediator variable distinction in social psychological research: Conceptual, strategic, and statistical considerations. Journal of Personality and Social Psychology, 51(6), 1173-1182.

Barrick, M. R., Mount, M. K., \& Li, N. (2013). The theory of purposeful work behavior: The role of personality, higher-order goals, and job characteristics. Academy of Management Review, 38(1), 132-153.

Bass, B. M. (1985). Leadership and performance beyond expectations. London: Collier Macmillan.

Bass, B. M. (1990). From transactional to transformational leadership: Learning to share the vision. Organizational Dynamics, 18(3), 19-31.

Bass, B. M. (1997). Does the transactional-transformational leadership paradigm transcend organizational and national boundaries? American Psychologist, 52(2), 130-139.

Bass, B. M. (1999). Two decades of research and development in transformational leadership. European Journal of Work \& Organizational Psychology, 8(1), 9-32.

Bass, B. M., \& Avolio, B. J. (1990). The implications of transactional and transformational leadership for individual, team, and organizational development. Research in Organizational Change \& Development, 4, 231-272.

Basu, R., \& Green, S. G. (1997). Leader-member exchange and transformational leadership: An empirical examination of innovative behaviors in leader-member dyads. Journal of Applied Social Psychology, 27(6), 477-499.

Bateman, T. S., \& Crant, J. M. (1993). The proactive component of organizational behavior: A measure and correlates. Journal of Organizational Behavior, 14(2), 103-118.

Bauer, D. J., \& Curran, P. J. (2005). Probing interactions in fixed and multilevel regression: Inferential and graphical techniques. Multivariate Behavioral Research, 40(3), 373-400.

Bednall, T. C., E. Rafferty, A., Shipton, H., Sanders, K., \& J. Jackson, C. (2018). Innovative Behaviour: How Much Transformational Leadership Do You Need? British Journal of Management, 29(4), 796-816.

Bertolino, M., Truxillo, D. M., \& Fraccaroli, F. (2011). Age as moderator of the relationship of proactive personality with training motivation, perceived career development from training, and training behavioral intentions. Journal of Organizational Behavior, 32(2), 248-263.

Beyer, J. M. (1999). Two approaches to studying charismatic leadership: Competing or complementary? Leadership Quarterly, 10(4), 575-588.

Bliese, P. D. (2000). Within-group agreement, non-independence, and reliability: Implications for data aggregation and analysis. In K. J. Klein \& S. W. J. Kozlowski (Eds.), Multilevel theory, research, and methods in organizations: Foundations, extensions, and new directions (pp. 349-381). San Francisco: Jossey-Bass.

Bono, J. E., \& Judge, T. A. (2003). Self-concordance at work: Toward understanding the motivational effects of transformational leaders. Academy of Management Journal, 46(5), 554-571.

Bowers, K. S. (1973). Situationism in psychology: An analysis and a critique. Psychological Review, 80(5), 307-336.

Braun, S., Peus, C., Weisweiler, S., \& Frey, D. (2013). Transformational leadership, job satisfaction, and team performance: A multilevel mediation model of trust. The Leadership Quarterly, 24(1), 270-283.

Brislin, R. W. (1980). Translation and content analysis of Oral and written material. In H. C. Triandis \& J. W. Berry (Eds.), Handbook of cross-cultural psychology (Vol. 2, pp. 389-444). Boston: Allyn and Bacon.

Brown, F. W., \& Reilly, M. D. (2008). Emotional intelligence, transformational leadership and gender: Correlation and interaction possibilities. The Journal of International Management Studies, 3(2), 1-9.

Bunderson, J. S., \& Sutcliffe, K. M. (2003). Management team learning orientation and business unit performance. Journal of Applied Psychology, 88(3), 552-560.

Burke, R. J. (2006). Why leaders fail: Exploring the dark side. International Journal of Manpower, 27(1), 91-100.

Burnett, M. F., Chiaburu, D. S., Shapiro, D. L., \& Li, N. (2015). Revisiting how and when perceived organizational support enhances taking charge: An inverted U-shaped perspective. Journal of Management, 41(7), 1805-1826.

Burns, J. M. (1978). Leadership New York. NY: Harper and Row Publishers.

Carter, M. Z., Armenakis, A. A., Feild, H. S., \& Mossholder, K. W. (2013). Transformational leadership, relationship quality, and employee performance during continuous incremental organizational change. Journal of Organizational Behavior, 34(7), 942-958.

Castro, C. B., Periñan, M. M. V., \& Bueno, J. C. C. (2008). Transformational leadership and followers' attitudes: The mediating role of psychological empowerment. International Journal of Human Resource Management, 19(10), 1842-1863.

Chan, D. (2006). Interactive effects of situational judgment effectiveness and proactive personality on work perceptions and work outcomes. Journal of Applied Psychology, 91(2), 475-481. 
Chan, S. C. H., Huang, X., Snape, E., \& Lam, C. K. (2013). The Janus face of paternalistic leaders: Authoritarianism, benevolence, subordinates' organization-based self-esteem, and performance. Journal of Organizational Behavior, 34(1), 108-128.

Charbonneau, D., Barling, J., \& Kelloway, E. K. (2001). Transformational leadership and sports performance: The mediating role of intrinsic motivation 1. Journal of Applied Social Psychology, 31(7), 1521-1534.

Chen, M. J. (2003). Transcending paradox: The Chinese "middle way" perspective. Asia Pacific Journal of Management, 20(1), 133-134.

Chen, M. J. (2008). Reconceptualizing the competition-Cooperation relationship: A transparadox perspective. Journal of Management Inquiry, 17(4), 288-304.

Conger, J. A., Kanungo, R. N. \& Menon, S. T. (2000). Charismatic leadership and follower effects. Journal of Organizational Behavior, 21(7), 747-767.

Crant, J. M. (2000). Proactive behavior in organizations. Journal of Management, 26(3), 435-462.

Deinert, A., Homan, A. C., Boer, D., Voelpel, S. C., \& Gutermann, D. (2015). Transformational leadership sub-dimensions and their link to leaders' personality and performance. Leadership Quarterly, 26(6), 1095-1120.

Dhanaraj, C., \& Beamish, P. W. (2004). Effect of equity ownership on the survival of international joint ventures. Strategic Management Journal, 25(3), 295-305.

Dionne, S. D., Yammarino, F. J., Atwater, L. E., \& Spangler, W. D. (2004). Transformational leadership and team performance. Journal of Organizational Change Management, 17(2), 177-193.

Dvir, T., Eden, D., Avolio, B. J., \& Shamir, B. (2002). Impact of transformational leadership on follower development and performance: A field experiment. Academy of Management Journal, 45(4), 735-744.

Dweck, C. S., \& Leggett, E. L. (1988). A social-cognitive approach to motivation and personality. Psychological Review, 95(2), 256-273.

Easterlin, R. A. (2005). Diminishing marginal utility of income? Caveat emptor. Social Indicators Research, 70(3), 243-255.

Edwards, J. R., \& Berry, J. W. (2010). The presence of something or the absence of nothing: Increasing theoretical precision in management research. Organizational Research Methods, 13(4), 668-689.

Eisenbeiss, S. A., \& Boerner, S. (2013). A double-edged sword: Transformational leadership and individual creativity. British Journal of Management, 24(1), 54-68.

Eisenbeiss, S. A., van Knippenberg, D., \& Boerner, S. (2008). Transformational leadership and team innovation: Integrating team climate principles. Journal of Applied Psychology, 93(6), 1438.

Eisenhardt, K. M. (2000). Paradox, spirals, ambivalence: The new language of change and pluralism. Academy of Management Review, 25(4), 703-705.

Eisenhardt, K. M., Furr, N. R., \& Bingham, C. B. (2010). CROSSROADS-Microfoundations of performance: Balancing efficiency and flexibility in dynamic environments. Organization Science, 21(6), 1263-1273.

Erkutlu, H. (2013). The impact of transformational leadership on organizational and leadership effectiveness. Journal of Management Development, 27(7), 708-726.

Felfe, J., \& Schyns, B. (2006). Personality and the perception of transformational leadership: The impact of extraversion, neuroticism, personal need for structure, and occupational self-efficacy. Journal of Applied Social Psychology, 36(3), 708-739.

Flaschner, A. B., Gill, A. S., \& Shachar, M. (2006). Mitigating stress and burnout by implementing transformational-leadership. International Journal of Contemporary Hospitality Management, 18(6), 469-481.

Fleishman, E. A. (1995). Consideration and structure: Another look at their role in leadership research. Monographs in Organizational Behavior and Industrial Relations, 24, 51-60.

Ford, R., \& Fottler, M. (1996). Empowerment: A matter of degree. IEEE Engineering Management Review, 24(3), 19-24.

Frieder, R. E., Wang, G., \& Oh, l.-S. (2018). Linking job-relevant personality traits, transformational leadership, and job performance via perceived meaningfulness at work: A moderated mediation model. Journal of Applied Psychology, 103(3), 324-333.

Fuller, J. B., \& Marler, L. E. (2009). Change driven by nature: A meta-analytic review of the proactive personality literature. Journal of Vocational Behavior, 75(3), 329-345.

Fuller, J. B., Marler, L. E., \& Hester, K. (2006). Promoting felt responsibility for constructive change and proactive behavior: Exploring aspects of an elaborated model of work design. Journal of Organizational Behavior, 27(8), 1089-1120.

Gilboa, S., Shirom, A., Fried, Y., \& Cooper, C. (2008). A meta-analysis of work demand stressors and job performance: Examining main and moderating effects. Personnel Psychology, 61(2), 227-271.

Gong, Y., Huang, J. C., \& Farh, J. L. (2009). Employee learning orientation, transformational leadership, and employee creativity: The mediating role of employee creative self-efficacy. Academy of Management Journal, 52(4), 765-778.

Grant, A. M., \& Schwartz, B. (2011). Too much of a good thing: The challenge and opportunity of the inverted U. Perspectives Psychological Science, 6(1), 61-76.

Grant, A. M., \& Sumanth, J. J. (2009). Mission possible? The performance of prosocially motivated employees depends on manager trustworthiness. Journal of Applied Psychology, 94(4), 927-944.

Howell, J. M., \& Avolio, B. J. (1992). The ethics of charismatic leadership: Submission or liberation? Executive, 6(2), 43-54.

Howell, J. M., \& Avolio, B. J. (1993). Transformational leadership, transactional leadership, locus of control, and support for innovation: Key predictors of consolidated-business-unit performance. Journal of Applied Psychology, 78(6), 891-902.

Howell, J. M., \& Shamir, B. (2005). The role of followers in the charismatic leadership process: Relationships and their consequences. Academy of Management Review, 30(1), 96-112.

Hurtz, G. M., \& Donovan, J. J. (2000). Personality and job performance: The big five revisited. Journal of Applied Psychology, 85(6), 869-879.

Janssen, O. (2001). Fairness perceptions as a moderator in the curvilinear relationships between job demands, and job performance and job satisfaction. Academy of Management Journal, 44(5), 1039-1050.

Jaussi, K. S., \& Dionne, S. D. (2003). Leading for creativity: The role of unconventional leader behavior. The Leadership Quarterly, $14(4-5), 475-498$.

Jiang, W., Gu, Q., \& Wang, G. G. (2015). To guide or to divide: The dual-side effects of transformational leadership on team innovation. Journal of Business \& Psychology, 30(4), 677-691.

Johns, A. M. (2001). Genre in the classroom: Multiple perspectives. New York: Routledge.

Judge, T. A., Bono, J. E., Erez, A., \& Locke, E. A. (2005). Core self-evaluations and job and life satisfaction: The role of selfconcordance and goal attainment. Journal of Applied Psychology, 90(2), 257-268.

Judge, T. A., Bono, J. E., \& Locke, E. A. (2000). Five-factor model of personality and transformational leadership. Journal of Applied Psychology, 85(5), 751-765. 
Judge, T. A., \& llies, R. (2002). Relationship of personality to performance motivation: A meta-analytic review. Journal of Applied Psychology, 87(4), 797-807.

Judge, T. A., \& Piccolo, R. F. (2004). Transformational and transactional leadership: A meta-analytic test of their relative validity. Journal of Applied Psychology, 89(5), 755-768.

Kark, R., Dijk, D. V., \& Vashdi, D. R. (2018). Motivated or demotivated to be creative: The role of self-regulatory focus in transformational and transactional leadership processes. Applied Psychology, 67(1), 186-224.

Kark, R., Shamir, B., \& Chen, G. (2003). The two faces of transformational leadership: Empowerment and dependency. Journal of Applied Psychology, 88(2), 246-255.

Keeley, M. (1995). The trouble with transformational leadership: Toward a federalist ethic for organizations. Business Ethics Quarterly, 5(1), 67-96.

Kim, T. Y., Hon, A. H. Y., \& Crant, J. M. (2009). Proactive personality, employee creativity, and newcomer outcomes: A longitudinal study. Journal of Business \& Psychology, 24(1), 93-103.

Kirkman, B. L., Chen, G. L., Farh, J. L., Chen, Z. X., \& Lowe, K. B. (2009). Individual power distance orientation and follower reactions to transformational leaders: A cross-level, cross-cultural examination. Academy of Management Journal, 52(4), $744-764$.

Kirkpatrick, S. A., \& Locke, E. A. (1996). Direct and indirect effects of three core charismatic leadership components on performance and attitudes. Journal of Applied Psychology, 81(1), 36-51.

Kissi, J., Dainty, A., \& Tuuli, M. (2013). Examining the role of transformational leadership of portfolio managers in project performance. International Journal of Project Management, 31(4), 485-497.

Klein, K. J., Bliese, P. D., Kozlowski, S. W., Dansereau, F., Gavin, M. B., Griffin, M. A., ... Bligh, M. C. (2000). Multilevel analytical techniques: Commonalities, differences, and continuing questions. In K. J. Klein, S. W. J. Kozlowski, Multilevel theory, research, and methods in organizations: Foundations, extensions, and new directions (512-553). San Francisco: JosseyBass.

Kohn, A. (1999). Punished by rewards: The trouble with gold stars, incentive plans, A's, praise, and other bribes. Boston, Massachusetts: Houghton Mifflin Harcourt.

Kohn, A. (2001). Five reasons to stop saying "good job". Young Children, 56(5), 24-28.

Kuhnert, K. W., \& Lewis, P. (1987). Transactional and transformational leadership: A constructive/developmental analysis. Academy of Management Review, 12(4), 648-657.

Lawrence, P. R., \& Lorsch, J. W. (1968). Organization and environment: Managing differentiation and integration. Administrative Science Quarterly, 13(1), 3459-3465.

Lechner, C., Frankenberger, K., \& Floyd, S. W. (2010). Task contingencies in the curvilinear relationships between intergroup networks and initiative performance. Academy of Management Journal, 53(4), 865-889.

Lee, S., Cheong, M., Kim, M., \& Yun, S. (2016). Never too much? The curvilinear relationship between empowering leadership and task performance. Group \& Organization Management, 42(1), 11-38.

Lepine, J. A., \& Van Dyne, L. (1998). Predicting voice behavior in work groups. Journal of Applied Psychology, 83(6), 853-868.

Lewis, D., French, E., \& Phetmany, T. (2000). Cross-cultural diversity, leadership and workplace relations in Australia. Asia Pacific Business Review, 7(1), 105-124.

Lewis, M. W. (2000). Exploring paradox: Toward a more comprehensive guide. Academy of Management Review, 25(4), 760-776.

Li, J., \& Yuan, B. (2017). Both angel and devil: The suppressing effect of transformational leadership on proactive employee's career satisfaction. International Journal of Hospitality Management, 65, 59-70.

Li, N., Liang, J., \& Crant, J. M. (2010). The role of proactive personality in job satisfaction and organizational citizenship behavior: A relational perspective. Journal of Applied Psychology, 95(2), 395-404.

Liao, H., \& Chuang, A. (2007). Transforming service employees and climate: A multilevel, multisource examination of transformational leadership in building long-term service relationships. Journal of Applied Psychology, 92(4), 1006.

Lim, B. C., \& Ployhart, R. E. (2004). Transformational leadership: Relations to the five-factor model and team performance in typical and maximum contexts. Journal of Applied Psychology, 89(4), 610-621.

Lord, R. G., De Vader, C. L., \& Alliger, G. M. (1986). A meta-analysis of the relation between personality traits and leadership perceptions: An application of validity generalization procedures. Journal of Applied Psychology, 71(3), 402-410.

Ma, L., \& Tsui, A. S. (2015). Traditional Chinese philosophies and contemporary leadership. Leadership Quarterly, 26(1), 13-24.

Manesh, M. H., \& Zanjirchi, S. M. (2013). Weighting indicators of employee performance evaluation using Taguchi experimental design approach. European Online Journal of Natural \& Social Sciences, 2(3(s)), 875-880.

Maslyn, J. M., \& Uhl-bien, M. (2001). Leader-member exchange and its dimensions: Effects of self-effort and other's effort on relationship quality. Journal of Applied Psychology, 86(4), 697.

Mathison, S. (1988). Why triangulate? Educational Researcher, 17(2), 13-17.

Menges, J., Walter, F., Vogel, B., \& Bruch, H. (2008). Mechanism and boundary conditions for performance effects of transformational leadership climate. Academy of Management Annual Meeting Proceedings, 2008(1), 1-6.

Menges, J. I., Walter, F., Vogel, B., \& Bruch, H. (2011). Transformational leadership climate: Performance linkages, mechanisms, and boundary conditions at the organizational level. Leadership Quarterly, 22(5), 893-909.

Mills, P. K., \& Ungson, G. R. (2003). Reassessing the limits of structural empowerment: Organizational constitution and trust as controls. Academy of Management Review, 28(1), 143-153.

Munir, F., Nielsen, K., Garde, A. H., Albertsen, K., \& Carneiro, I. G. (2012). Mediating the effects of work-life conflict between transformational leadership and health-care workers' job satisfaction and psychological wellbeing. Journal of Nursing Management, 20(4), 512-521.

Ng, T. W. (2017). Transformational leadership and performance outcomes: Analyses of multiple mediation pathways. The Leadership Quarterly, 28(3), 385-417.

Olsen, W. (2004). Triangulation in social research: Qualitative and quantitative methods can really be mixed. Developments in Sociology, 20, 103-118.

Organ, D. W., \& Paine, J. B. (1999). A new kind of performance for industrial and organizational psychology: Recent contributions to the study of organizational citizenship behavior. In C. L. Cooper \& I. T. Robertson (Eds.), International review of industrial and organizational psychology (Vol. 14, pp. 337-368). New York: Wiley.

Osborn, R., \& Marion, R. (2009). Contextual leadership, transformational leadership and the performance of international innovation seeking alliances. The Leadership Quarterly, 20(2), 191-206. 
Ostroff, C., \& Bowen, D. (2016). Reflections on the 2014 decade award: : Is there strength in the construct of hr system strength? Academy of Management Review, 41(2), 196-214.

Pan, S. Y., \& Lin, K. J. (2015). Behavioral mechanism and boundary conditions of transformational process. Journal of Managerial Psychology, 30(8), 970-985.

Parker, S. K., Bindl, U. K., \& Strauss, K. (2010). Making things happen: A model of proactive motivation. Journal of Management, 36(4), 827-856.

Peng, K., \& Nisbett, R. E. (1999). Culture, dialectics, and reasoning about contradiction. American Psychologist, 54(9), 741-754.

Pierce, J. R., \& Aguinis, H. (2011). The too-much-of-a-good-thing effect in management. Journal of Management, 39(2), 313-338.

Pierce, J. R., \& Aguinis, H. (2013). Detrimental citizenship behavior: A multilevel framework of antecedents and consequences. Management \& Organization Review, 11(1), 69-99.

Pieterse, A. N., Van Knippenberg, D., Schippers, M., \& Stam, D. (2010). Transformational and transactional leadership and innovative behavior: The moderating role of psychological empowerment. Journal of Organizational Behavior, 31(4), 609-623.

Podsakoff, P. M., MacKenzie, S. B., Moorman, R. H., \& Fetter, R. (1990). Transformational leader behaviors and their effects on followers' trust in leader, satisfaction, and organizational citizenship behaviors. The Leadership Quarterly, 1(2), 107-142.

Podsakoff, P. M., Mackenzie, S. B., \& Podsakoff, N. P. (2012). Sources of method bias in social science research and recommendations on how to control it. Annual Review of Psychology, 63(1), 539.

Porter, L. W., \& Bigley, G. A. (2003). Motivation and transformational leadership: Some organizational context issues. In R. W. Allen, L. W. Porter, \& H. L. Angle (Eds.), Organizational influence processes (pp. 263-274). New York: Routledge.

Rabin, M., Kahneman, D., \& Tversky, A. (2001). Diminishing marginal utility of wealth cannot explain risk aversion. UC Berkeley: Department of Economics, UCB.

Ren, S., \& Chadee, D. (2017). Is guanxi always good for employee self-development in China? Examining non-linear and moderated relationships. Journal of Vocational Behavior, 98, 108-117.

Resick, C. J., Whitman, D. S., Weingarden, S. M., \& Hiller, N. J. (2009). The bright-side and the dark-side of CEO personality: Examining core self-evaluations, narcissism, transformational leadership, and strategic influence. Journal of Applied Psychology, 94(6), 1365-1381.

Robalino, D., Vodopivec, M., Bodor, A. (2009). Savings for unemployment in good or bad times: options for developing countries. IZA Discussion Paper No. 4516. Available at SSRN: https://ssrn.com/abstract=1501932.

Schad, J., Lewis, M. W., Raisch, S., \& Smith, W. K. (2016). Paradox research in management science: Looking Back to move forward. Academy of Management Annals, 10(1), 1-60.

Seibert, S. E., Crant, J. M., \& Kraimer, M. L. (1999). Proactive personality and career success. Journal of Applied Psychology, 84(3), 416-427.

Seibert, S. E., Kraimer, M. L., \& Crant, J. M. (2001). What do proactive people do? A longitudinal model linking proactive personality and career success. Personnel Psychology, 54(4), 845-874.

Seibert, S. E., Wang, G., \& Courtright, S. H. (2011). Antecedents and consequences of psychological and team empowerment in organizations: A meta-analytic review. Journal of Applied Psychology, 96(5), 981-1003.

Shamir, B. (2007). From passive recipients to active co-producers: The roles of followers in the leadership process. In B. Shamir, R. Pillai, M. Bligh, \& M. Uhl-Bien (Eds.), Follower-centered perspectives on leadership: A tribute to J. R. Meindl. Stamford: Information Age Publishing.

Shamir, B., House, R. J., \& Arthur, M. B. (1993). The motivational effects of charismatic leadership: A self-concept based theory. Organization Science, 4(4), 577-594.

Shin, S. J., \& Zhou, J. (2003). Transformational leadership, conservation, and creativity: Evidence from Korea. Academy of Management Journal, 46(6), 703-714.

Smith, W. K., \& Lewis, M. W. (2011). Toward a theory of paradox: A dynamic equilibrium model of organizing. Academy of Management Review, 36(2), 381-403.

Smith, W. K., \& Tushman, M. L. (2005). Managing strategic contradictions: A top management model for managing innovation streams. Organization Science, 16(5), 522-536.

Sonnentag, S. (2003). Recovery, work engagement, and proactive behavior: A new look at the interface between nonwork and work. Journal of Applied Psychology, 88(3), 518-528.

Spector, P. E., Dwyer, D. J., \& Jex, S. M. (1988). Relation of job stressors to affective, health, and performance outcomes: A comparison of multiple data sources. Journal of Applied Psychology, 73(1), 11.

Spencer-Rodgers, J., Peng, K., Wang, L., \& Hou, Y. (2004). Dialectical self-esteem and east-west differences in psychological well-being. Personality \& Social Psychology Bulletin, 30(11), 1416-1432.

Spreitzer, G. M., Perttula, K. H., \& Xin, K. (2005). Traditionality matters: An examination of the effectiveness of transformational leadership in the United States and Taiwan. Journal of Organizational Behavior, 26(3), 205-227.

Stone, A. G., Russell, R. F., \& Patterson, K. (2004). Transformational versus servant leadership: A difference in leader focus. Leadership \& Organization Development Journal, 25(4), 349-361.

Summers, J. J., Rosenbaum, D. A., Burns, B. D., \& Ford, S. K. (1993). Production of polyrhythms. Journal of Experimental Psychology Human Perception \& Performance, 19(2), 416-428.

Thompson, J. A. (2005). Proactive personality and job performance: A social capital perspective. Journal of Applied Psychology, 90(5), 1011-1017.

Tosi, H. L., Misangyi, V. F., Fanelli, A., Waldman, D. A., \& Yammarino, F. J. (2004). CEO charisma, compensation, and firm performance. Leadership Quarterly, 15(3), 405-420.

Tourish, D. (2013). The dark side of transformational leadership: A critical perspective. New York: Routledge.

Tourish, D., \& Pinnington, A. (2002). Transformational leadership, corporate cultism and the spirituality paradigm: An unholy trinity in the workplace? Human Relations, 55(2), 147-172.

Tse, H. H. M., \& Chiu, W. C. K. (2014). Transformational leadership and job performance: A social identity perspective. Journal of Business Research, 67(1), 2827-2835.

Tse, H. H. M., Huang, X., \& Lam, W. (2013). Why does transformational leadership matter for employee turnover? A multi-foci social exchange perspective. Leadership Quarterly, 24(5), 763-776.

Tsui, A. S., Pearce, J. L., Porter, L. W., \& Tripoli, A. M. (1997). Alternative approaches to the employee-organization relationship: Does investment in employees pay off? Academy of Management Journal, 40(5), 1089-1121. 
Uhl-Bien, M., Riggio, R. E., Lowe, K. B., \& Carsten, M. K. (2014). Followership theory: A review and research agenda. The Leadership Quarterly, 25(1), 83-104.

Uhl-bien, M., Schermerhorn Jr., J. R., \& Osborn, R. N. (2004). Organizational Behavior (13th ed.). Beijing: Tsinghua University Press.

Vandewalle, D., Brown, S. P., Cron, W. L., \& Slocum, J. W. (1999). The influence of goal orientation and self-regulation tactics on sales performance: A longitudinal field test. Journal of Applied Psychology, 84(2), 249-259.

Villiers, R. D. (2014). Book essay on "the dark side of transformational leadership: A critical perspective". Journal of Business Research, 67(12), 2512-2514.

Voigtländer, M. (2016). Transaction costs: A high financial burden for German home buyers. Retrieved from http://hdl.handle. net/10419/157578

Walton, M. (2014). The dark side of transformational leadership: A critical perspective. Action Learning: Research and Practice, $11(2), 238-240$.

Walumbwa, F. O., Avolio, B. J., \& Zhu, W. (2008). How transformational leadership weaves its influence on individual job performance: The role of identification and efficacy beliefs. Personnel Psychology, 61(4), 793-825.

Wang, G., Oh, I.-S., Courtright, S. H., \& Colbert, A. E. (2011). Transformational leadership and performance across criteria and levels: A meta-analytic review of 25 years of research. Group \& Organization Management, 36(2), 223-270.

Wang, H., Law, K. S., Hackett, R. D., Wang, D., \& Chen, Z. X. (2005). Leader-member exchange as a mediator of the relationship between transformational leadership and Followers' performance and organizational citizenship behavior. Academy of Management Journal, 48(3), 420-432.

Webb, E. J., Campbell, D. T., Schwartz, R. D., \& Sechrest, L. (1966). Unobtrusive measures: Nonreactive research in the social sciences (Vol. 111). Chicago: Rand McNally.

Weiß, E., \& Süß, S. (2016). The relationship between transformational leadership and effort-reward imbalance. Leadership \& Organization Development Journal, 37(4), 450-466.

Wen, F.-H., \& Chiou, H.-J. (2009). Methodology of multilevel modeling: The key issues and their solutions of hierarchical linear modeling. NTU Management Review, 19(2), 263-294.

Williams, L. J., \& Anderson, S. E. (1991). Job satisfaction and organizational commitment as predictors of organizational citizenship and in-role behaviors. Journal of Management, 17(3), 601-617.

Yukl, G. (1989). Managerial leadership: A review of theory and research. Journal of Management, 15(2), 251-289.

Yukl, G. (2009). Leading organizational learning: Reflections on theory and research. Leadership Quarterly, 20(1), 49-53.

Yun, S., Faraj, S., \& Jr, S. H. (2005). Contingent leadership and effectiveness of trauma resuscitation teams. Journal of Applied Psychology, 90(6), 1288-1296.

Zettler, I., \& Lang, J. W. (2015). Employees' political skill and job performance: An inverted U-shaped relation? Applied Psychology, 64(3), 541-577.

Zhang, X. a., Cao, Q., \& Tjosvold, D. (2011). Linking transformational leadership and team performance: A conflict management approach. Journal of Management Studies, 48(7), 1586-1611.

Zhang, Y., Waldman, D. A., Han, Y. L., \& Li, X. B. (2015). Paradoxical leader behaviors in people management: Antecedents and consequences. Academy of Management Journal, 58(2), 538-566.

\section{Submit your manuscript to a SpringerOpen ${ }^{\circ}$ journal and benefit from:}

- Convenient online submission

- Rigorous peer review

- Open access: articles freely available online

- High visibility within the field

- Retaining the copyright to your article

Submit your next manuscript at $\mathbf{s p r i n g e r o p e n . c o m ~}$ 